\title{
KONSEP MAQĀṢID ASY-SYARĪ'AH, KRITIK ATAS NALAR LIBERALIS
}

\author{
SOFYAN SULAIMAN \\ Fakultas Agama Islam, Universtias Islam Indragiri \\ sofyan_sulaiman@unisi.ac.id
}

\begin{abstract}
The discussion of the maqāșid syari'ah is so prominent in the discussion of Islamic law. This is due to the response of Muslim scholars to the current social reality of the ummah. At least there are two opposing camps, first, the revivalists (mujaddid) who want the Shari'a are carried out according to what they are ordered to get mashlahah, while the second group, liberals, only want the substance to be carried out by ignoring the sharia text. This article is in response to the views of Muslim scholars, how the real maqashid concept is in Islam.
\end{abstract}

Keywords: Syariah, MaqashidSyariah, Hukum Islam

\section{PENDAHULUAN}

Konsepsi hukum dalam ajaran Islam berbeda dengan konsepsi hukum pada umumnya, khususnya hukum modern. Dalam Islam hukum dipandang sebagai bagian dari ajaran agama, dan norma-norma hukum bersumber kepada agama. Umat Islam meyakini bahwa hukum Islam berdasarkan kepada wahyu llahi. Oleh karena itu, ia disebut syari'ah (Anwar, 2007). Namun demikian. Syariah itu sepenuhnya diterapkan dalam kehidupan sosial masyarakat manusia, diinterpretasikan dan dijabarkan oleh aktivitas intelektual manusia dalam merespons berbagai problem yang dihadapi manusia disamping ketentuan-ketentuan yang secara langsung ditetapkan dalam wahyu llahi (Anwar, 2007).

Secara harfiah, kata "syari ah" berarti jalan, dan lebih khusus lagi jalan menuju ke tempat air. Dalam pemakaian religiusnya syariah berarti jalan yang digariskan Tuhan menuju kepada keselamatan atau lebih tepatnya jalan jalan menuju Tuhan. Ajaran-ajaran yang dibawa oleh Nabi Muhammad disebut syari'ah karena merupakan jalan menuju Tuhan dan menuju keselamatan abadi (Anwar, 2007)

Dalam arti luas, syari'ah dimaksudkan sebagai keseluruhan 
ajaran dan norma-norma yang dibawa oleh Nabi Muhammad yang mengatur kehidupan manusia baik dalam aspek kepercayaannya maupun dalam aspek tingkah laku praktisnya. Singkatnya syari'ah adalah ajaran-ajaran agama Islam itu sendiri, yang dibedakan menjadi dua aspek: (1) ajaran tentang kepercayaan (akidah) dan (2) ajaran tentang tingkah laku (amaliah). Dalam hal ini, dalam arti luas identik dengan syara' (asy-syar') dan ad-din (agama Islam) (Anwar, 2007).

Dalam arti sempit, syariah merujuk kepada aspek praktis (amaliah) dari syariat dalam arti luas, yaitu aspek yang berupa kumpulan ajaran atau norma yang mengatur tingkah laku konkret manusia. Syariat dalam arti sempit inilah yang lazimnya diidentikkan dan diterjemahkan sebagai hukum Islam. Hanya saja, syariah dalam arti sempit ini lebih luas dari sekedar hukum pada umumnya, karena syariah dalam arti sempit tidak hanya meliputi norma hukum itu sendiri, tetapi norma etika atau kesusilaan, norma sosial, dan norma keagamaan (seperti ibadah) yang diajarkan Islam (Anwar, 2007).

Seluruh ulama sepakat bahwa syariat Islam diturunkandengan tujuan, yaitu demi untuk kebaikan manusia, di dunia ini terlebih lagi di akhirat. Imam Ibnu Qayyim menuliskan seperti berikut

Sesungguhnya dasar dan fondasi syariat Islam adalah hikmah dan kebaikan manusia di dunia dan akhirat. Syari'at Islam itu seluruhnya adil, rahmah, hikmah, dan maslahah. Oleh sebab itu setiap masalah yang lari dari prinsip keadilan kepada kezaliman, atau dari rahmah kepada sebaliknya, atau dari kebaikan menuju mafsadah, atau dari hikmah kepada hal yang sia-sia bukan merupakan bagian syari'at meskipun dimasuki melalui ta'wil (Al-Qayyim) Imam asy-Syāțibī menyatakan

Seluruh umat Muslim - bahkan umat lainnya sepakat bahwa syari'at ditetapkan untuk menjaga lima unsur pokok di dalam kehidupan manusia, yaitu; agama, jiwa, nasab, harta, serta akal yang kemudian disebutka sebagai al-mashalih adh-dharuriyah. Pengetahuan serta kesepakatan ini berlaku secara alami dan pasti tanpa memerlukan adanya dalil-dalil khusus karena hal-hal tersebut dapat dikeahui secara langsung dalam berbagai aspek kehidupan manusia Al-Syatibi, 1997)

Tujuan dari syari'ah tersebut dikenal dengan maqashid asysyariah. Kajian dari maqașid asysyariah timbul karena, pertama, upaya ulama untuk memberikan pemahaman kepada umat Islam terhadap setiap perintah yang diberikan oleh Syāri'. Seperti yang telah di mulai oleh Imam at-Tirmidzi dengan bukunya aș-Șalah wa Maqāșiduha (Auda, 2007). Kedua, bahwa Islam dihadapkan pada problem permananen (qat $t^{\prime} i$ ) yaitu terbatasnya jumlah teks (al-Qur'an dan Sunnah), semantara berbagai kejadian dan dinamika masyarakat selalu bergulir dan melahirkan permasalahan semakin rumit dan komplit (Asmuni, 2012), sehingga diperlukan pemahaman terhadap teks syariah secara mendalam, seperti yang dilakukan oleh Imam asy-Syāțibī.

Pembahasan terhadap maqāșid ini pada akhir-akhir ini kemudian menjadi perdebatan. Ada yang memahami maqāșid hanya sebagai hikmatul hukum, artinya tujuan syariah itu bukanlah sebagai hukum, namun efek positif dari 
pelaksanaan syari'ah. Namun beberapa cendikiawan liberal lebih menginginkan sebagai 'illatul hukum, artinya tujuan itu menjadi penyebab terjadinya hukum, sehingga hukum bisa berubah seiring berubahnya zaman. Misal, jika tujuan potong tangan adalah menghukum pencuri, maka dengan penjara cukup membuat pencuri jera, tidak perlukan adanya potong tangan. Isu inilah yang ingin penulis angkat dalam artikel ini.

\section{DEFENISI DAN SEJARAH TEORITISI MAQĀȘID SYARĪ'AH}

Istilah maqāṣid - jamak dari kata maqșid - merujuk kepada tujuan, sasaran, sesuatu yang bersifat prinsip, sesuatu yang diharapkan, atau tujuan akhir. Maqāṣiddalam hukum Islam merupakan tujuan atau sasaran dari syari'ah Islam (Auda, 2007). Dalam dunia pemikiran Islam, kajian tentang maqāșidasy-syarīah sama sekali bukan merupakan topik baru. Ahmad Rasyuni menelusuri akar kajian ini se-awal Imam at-Turmidzi (w. $3 \quad \mathrm{H}$ ). $\quad$ Turmidzi telah menggunakan perkataan maqāșid sebagai judul bukunya as-Ṣalāh wa Maqāsiduha, yang menguraikan tentang rahasia shalat. Ide ini kemudian dikembangkan oleh ulama-ulama berikutnya seerrti Abu Masnur al-Maturidi (w. $333 \mathrm{H}$ ), Abu Bakar al-Qaffal al-Syasyhi (w. 365 H), Abu Bakar al-Abhari (w. $375 \mathrm{H}$ ), dan Imam al-Baqilani (w. $403 \mathrm{H}$ ) (AlRaysini, 2005). Imam Juwaini juga memainkan peran dalam pengembangan konsep ini, bahkan yang paling awal merumuskan maqāșidsebagai sebuah teori. Diantara ungkapan Imam Juwaini yang terpenting adalah "barang siapa yang tidak memahami obyetif perintah (awamir) dan larangan (nawahi) Allah, maka sesungguhnya dia tidak memiliki kemampuan untuk menetapkan sesuatu hukum." (AlRaysini, 2005).

$$
\text { Imam Al-Ghazali (w.505 H), }
$$

murid Imam Juwaini, kemudian mensistemkan konsep ini dengan membaginya kepada tiga kategori, daruriyyah, hajiyyah, dan tahsiniyyah (Al-Raysini, 2005). Fakhruddin alRazi (w. $606 \mathrm{H}$ ) tidak memberikan banyak kontribusi dalam pengembangan ide ini. Hal ini, kata Rasyuni, tidak mengherankan karena memang kitab al-Mashul fi Ușul al-Fiqh karya al-Razi ini hanya merupakan ringkasan dari Mu'tamad-nya Abu Husayn al-Basri, al-Burhan-nya Imam Juwaini, dan Mustașfa-nya Imam al-Ghazali. Demikian pula, Razi patut dipuji karena dia telah bersunguh-sungguh mempertahankan rasionalisasi hukum (ta'lil al-ahkam), ketika konsep ini mulai mengalami proses degradasi. Kata al-Razi "maslahah hendaklah menjadi bagian dari syari'iah, karena tujuan utama keseluruhan hukum yang diperintahkan Allah adalah untuk memelihara dan menjaga kemaslahatan." (Al-Raysini, 2005).

Untuk beberapa lama konsep maqasid mengalami proses stagnasi seiring dengan mandeknya wacana keilmuan di dunia Islam. Figh Islam menjadi kaku dan baku, dan yang berkembang sebaliknya adalah tradisi taqlid. Di tengah-tengah kemandekan inilah Imam al-Syatibi tampil dengan manum opus-nya alMuwafaqat dimana beliau menjabarkan dengan begitu terperinci sekali tenang konsepmaqāșidal-syarīah. Ibnu 'Asyur yang juga memainkan peran penting dalam pengembangan teori 
ini dengan kitabnya MaqāșidalSyariah memuji kehebatan buku Imam al-Syāțibi dengan katakatanya:

Sungguh dengan kitab ini Syāțibī telah membangun peradaban Islam. Dengan buku ini ia dapat menunjukkan jalan dan cara merealisasikan kabadian dan kesucian ad-din. Hanya sedikit orang saja sebelumnya yang mendapatkan jalan ini (Al-Raysini, 2005).

Begitu hebatnya kontribusi Syatibi sehingga konsep maqāșidini telah menjadi bagian yang tak terpisahkan dari hukum syariah Islam hari ini.

\section{KONSEP MAQĀȘIDASY-SYARĪ'AH}

Dalam artikel ini penulis mengangkat konsepmaqāșidyang dirumuskan oleh Imams al-Syāțibī secara ringkas. Sebagaimana yang dijelaskan sebelumnya Imam alSyāțibī memberikan kontribusi yang begitu besar dalam teori ini. Keunikan konsep maqāșidlmam alSyāțibīterletak pada perhatiannya akan kakuknya fiqh pada abad ke VIII di Andalusia, kakunya untuk mengelola perubahan sosialekonomi pada zaman itu. Maka, Imam Syāțibīberusaha untuk merespon tuntunan-tuntunan dengan menunukkan bagaimna syari'ah dapat dikondisikan dalam konteks sosial yang baru.

Dalam bukunya al-Muwāfaqāt fi Ușul al-Ahkam, Imam Syāțibī menyatakan, seluruh umat Islam sepakat bahwa syariat ditetapkan untuk menjaga lima unsur pokok di dalam kehidupan manusia, yaitu: agama, jiwa, nasab, harta, serta akal (Al- Shatibi, 1997). Dalam pembahasannya, Imam Syāțibīmembagi maqāṣid al-syari'ah berdasarkan tiga sisi
Pertama, klasifikasi dari sisi sumbernya, terbagi ke dalam dua kategori; (1) Qașdu asy-Syāri' (tujuan pembuat syariat, Allah), dan (2) qașdu al-mukallaf (tujuan penerima syariat, manusia). Pembagian ini tercermin dengan keberadaan tujuan pembuat syariat yang mencakup seluruh kemaslahatan bagi umat manusia berikut penyelarasan antara tujuan manusia (mukallaf) dengan pembuat syariat (Syāri) (Tim Penulis MSI-UII, 2012).

Kedua, klasifikasi dari sisi universalitas, terbagi menjadi dua kategori: Maqāșidkulliyah dan juz'iyah. Maqāșidkulliyah adalah tujuan syariah universal yang secara tangkas dapat dipahami oleh akal kita. Sedangkan yang dimaksud dengan maqāșidjuz'iyah adalah tujuan-tujuan yang bersifat spesifik pada satu hukum, dan biasa diungkapkan oleh fuqaha dengan istilah hikmah, rahasia, atau sebab hokum (Tim Penulis MSI-UII, 2012).

Ketiga, pembagian dari sisi orisinilitas, terbagi ke dalam dua kategori yaitu așliyah (primer) dan tabiliyah (sekunder). Maqāșidașliyah adalah tujuan utama yang sengaja direncanakan oleh Syāri' seperti "terciptanya regenerasi umat manusia" merupakan tujuan utama dari disyariatkannya pernikahan dan terpenuhi kebutuhan biologis bagi pasangan suami istri merupakan maqāșidtabilyah (tujuan sisipan) atau sebagai konsekuensi untuk melengkapi tujuan utama (Tim Penulis MSI-UII, 2012).

Menurut Imam Syāțibī, QashduSyari' (tujuaan pembuat syariat) di bagi menjadi empat bagian, yaitu: 


\section{Qașdu asy-Syāri' fi Waḍ'i asy- Syarīah (Tujuan Syāri’ dalam menetapkan syari'at)}

Allah menurunkan syariat (aturan hukum) tiada lain agar manusia dapat mengambil kemashlahatan dan menghindari kemudharatan (jalbu al-mashalih wa dar'u al-mafasid). Dengan bahasa yang lebih mudah, aturan-aturan hukum yang Allah tentukan hanyalah untuk kemashlahatan manusia itu sendiri. Imam Syāțibīkemudian membagi mashlahat ini kepada tiga bagian penting yaitu; darūriyah (primer), hajiyah (sekunder) dan tahsiniyyat (tersier) (Al- Shatibi, 1997).

Mashlahatad-daruriyyat adalah sesuatu yang mesti adanya demi terwujudnya kemashlahatan agama dan dunia. Apa bila hal ini tidak ada, maka akan menimbulkan kerusakan bahkan hilangnya hidup dan kehidupan seperti makan, minum, shalat, dan shaum. Yang termasuk maslahat atau maqāșidadhdaruriyah ini ada lima yaitu, hifzh addin (agama), an-nafs (jiwa), an-nasl (keturunan/kehormatan), al-mal (harta), dan al-aql (akal) (Al- Shatibi, 1997).

Cara untuk menjaga yang lima hal tersebut dapat ditempuh dengan dua cara, yatiu: (1) dari aspek positif (min janibi al-wujud), yaitu dengan cara menjaga dan memelihara halhal yang dapat keberlangsungan keberadaadnya. Dan (2) dari aspek negatif (min janibi al-'adam) yaitu dengan cara mencegah hal-hal yang menyebabkan ketiadaannya (AlShatibi, 1997). Sebagai aplikasinya adalah:

a. Menjaga agama dari aspek positif misalnya shalat dan zakat, sedangkan dari aspek negatif misalnya jihad dan hukuman bagi orang yang murtad.

b. Menjaga jiwa dari aspek positif misalnya makan dan minum, sedangkan dari aspek negatif misalnya hukuman qishas dan diyat.

c. Menjaga akal dari aspek positif misalnya mencari ilmu, sedangkan dari aspek negatif misalnya hukuman had bagi peminum khamar

d. Menjaga keturunan ari aspek positif misalnya nikah, sedangkan dari aspek negatif misalnya had bagi yang berzina.

e. Menjaga harta dari aspek positif misalnya perintah jual-beli dan mencari rizki dari aspek negatif misalnya larangan melakukan ribawi dan menghukum para pencuri.

Mashlahathajiyyat adalah sesuatu yang sebaiknya ada agar manusia dapat secara leluasa memenuhi kebutuhan mereka tanpa mengalami kesulitan. Namun demikian kalau kebutuhan ini tidak terpenuhi, tidak akan menyebabkan kematian atau kerusakan (Tim Penulis MSI-UII, 2012). Misalnya dalam hal ibadah: rukhșah dalam masalah ibadah, jama' dan qashar shalat bagi musafir.

Mashlahattahsiniyyat adalah sesuatu yang sebaiknya ada untuk memperindah kehidupan. Namun demikian kalau kebutuhan ini tidak terpenuhi tidak akan menimbulkan masyaqqah atau kesempitan, apalagi kerusakan (Tim Penulis MSIUII, 2012). Hanya saja kehidupan terasa kurang indah dan anggun. Misalnya; thaharah, menutup aurat dan menghilangkan najis.

2. Qashdu asy-syari' fi wadh'i asy-syari'ah lil-Ifham (Tujuan 
Syari' dalam menetapkan Syari'at agar dapat dipahami)

Ada dua hal yang penting dalam bagian ini: Pertama, syariah ini diturunkan dalam bahasa Arab, firman Allah:

Sesungguhnya Kami menurunkannya berupa Al Quran dengan berbahasa Arab, agar kamu memahaminya. (QS. Yusuf: 2)

Oleh karenanya, untuk memahami syari'ah harus terlebih dahulu memahami barbagai aspek yang berhubungan dengan bahasa Arab, baik itu tata bahasa, gaya bahasa dan cara pemaknaannya.

Selai itu juga diperlukan ilmuilmu lain yang erat kaitannya dengan lisan Arab seperti Ushul Fiqh, Mantiq, IImu Ma'ani dan yang lainnya. Karenanya, tidaklah heran apabila penguasaan beberapa ilmu tersebut termasuk dalam persyaratan pokok yang harus dimiliki seorang mujtahid (Tim Penulis MSI-UII, 2012).

Kedua, bahwa syariat ini bersifat ummiyah, artinya untuk memahami tidak membutuhkan bantuan ilmu-ilmu alam seperti ilmu matematika, kimia, fisika dan lainnya. Hal ini dimaksudkan agar syari'ah mudah dipahami oleh semua lapisan masyarakat. Apabila untuk memahami syariat ini memerlukan bantuan seperti ilmu alam, setidaknya akan menimbulkan dua kendala besar yang akan dihadapi manusia pada umumnya, yaitu kendala dalam hal memahami dan melaksanakan syari'ah. Untuk itulah berangkat dari sifatnya yang ummiyah, syari'ah mudah dipahami oleh siapa pun dan dari disiplin ilmu apapun, karena ia berpangkal pada maslahah (Tim Penulis MSI-UII, 2012).

\section{Qashdu asy-Syari' fi Wadh'i asy-Syari'ah li at-Taklif bi Muqthada}

Bahwa tujuan Syari' dalam menentukan syariat adalah untuk dilaksanakan sesuai dengan yang dituntutnya (Al- Shatibi, 1997). Ada dua hal yang penting dalam permasalahan ini, yaitu:

Pertama, tuntutan yang di luar kemampuan manusia (at-taklif bi-ma la yuhaq). Mengenai hal ini Imam Syathibi mengatakan, "setiap taklif yang di luar batas kemampuan manusia, maka secara syar'i taklif itu tidak sah meskipun akal membolehkannya." (Al- Shatibi, 1997).

Apabila teks syari'ah terdapat redaksi yang mengisayaratkan perbuatan di luar kemampuan manusia, maka harus dilihat pada konteks, unsur-unsur lain, atau redaksi sebelumnya. Misalnya firman Allah,

Hai orang-orang yang beriman, bertakwalah kepada Allah sebenar-benar takwa kepada-Nya; dan janganlah sekali-kali kamu mati melainkan dalam keadaan beragama Islam. (QS. Ali Imran: 102)

Ayat ini bukan berarti larangan untuk mati karena mencegah kematian adalah di luar batas kemampuan manusia. Maksud larangan ini adalah larangan untuk memisahkan antara keislaman dengan kehidupan di dunia ini karena datangnya kematian tidak ada seorangpun yang mengetahuinya.

Begitu juga dengan sabda Nabi, "jangan kamu marah" (AlHassan, 2016), tidak berarti melarang marah, karena marah adalah tabiat manusia yang tidak mungkin dapat dihindari. Akan tetapi, 
yang dimaksud oleh hadits ini adalah agar sedapat mungkin seseorang menahan diri ketika marah atau menghindari hal-hal yang mangakibatkan marah.

Kedua, tuntutan yang di dalamnya terdapat musyaqqah/kesulitan (al-taklif bi-mā fi-hi musyaqqah). Menurut Imam Syāțibī,Syāri' tidak bermaksud menimbulkan musyaqqah dengan menetapkan taklif bagi para mukallaf, akan tetapi sebaliknya, di dalamnya pasti terdapat manfaat bagi mukallaf (Al- Shatibi, 1997).

Bila dianalogikan kepada kehidupan sehari-hari, ketika seorang dokter memberikan obat pahit kepada pasiennya bukan berarti ia memberikan kesulitan baru bagi si pasien, akan tetapi hal itu demi kesehatan pasien itu sendiri pada masa berikutnya.

Dalam masalah agama misalnya, ketika ada kewajiban jihad, maka sesungguhnya hal itu tidak dimaksudkan untuk menceburkan diri dalam kebinasaan, tetapi untuk kemashlahatan manusia itu sendiri yaitu sebagai wasilah (sarana) amar ma'ruf nahy munkar. Demikan pula dengan hukum potong tangan bagi pencuri, tidak dimaksudkan untuk merusak anggota badang, akan tetapi demi terpeliharanya harta orang lain.

Apabila ada masyaqqah dalam taklif, maka sebetulnya bukanlah masyaqqah melainkan kulfah (konsekuensi/keharusan), sesuatu yang tidak mungkin dapat dipisahkan dari kegiatan manusia sebagaimana dalam kacamata kebiasaan manusia, orang yang memikul barang atau bekerja siang malam untuk mencari kehidupan tidak dipandang sebagai musyaqqah, tetapi sebagai salah satu keharusan dan kelaziman untuk mencari nafkah. Demikian halnya dengan masalah ibadah. Musyaqqah ini menurut Imam Syāțibīdisebut masyaqqahmu'tadah karena dapat diterima dan dilaksanakan oleh anggota badan. oleh karena itu dalam syara'hal itu tidak dipandang sebagai musyaqqah.

Yang dipandang sebagai musyaqqah adalah apa yang disebutnya dengan musyaqqahghairmu'tadah atau ghair 'adiyyah, yiatu masyaqqah yang tidak lazim dan tidak dapat dilaksanakan, atau apabila dilaksanakan akan menimbulkan kesulitan dan kesempitan. Misalnya, keharusan berpuasa bagi orang sakit dan orang jompo. Semua ini adalah

masyaqqahghairmu'tadahyang

dikecam oleh Islam. Untuk mengatasi masyaqqah ini, Islam memberikan jalan keluar melalui rukhsah (keringanan).

\section{Qashdu asy-Syari' fi Dukhul al-Mukallaf tahta Ahkam asy- Syari'ah}

Syari' memerintahkan mukallaf harus melaksanakan syari'ah, hal ini untuk melindungi dan membebaskan mukallaf dari tuntutan dan keinginan hawa nafsunya sehingga ia menjadi seorang hamba yang dalam istilah Imam Syāțibīdisebut sebagai hamba Allah yang ikhtiyaran dan bukan idthiraran. Setiap perbuatan yang mengikuti hawa nafsu, maka ia batal dan tidak ada manfa'atnya. Sebaliknya, setiap perbuatan harus senantiasa mengikuti petunjuk Syāri' dan bukan mengiktui hawa nafsu (Al- Shatibi, 1997).

Dari konsep yang dibuat oleh Imam Syathibi ini bisa kita lihat penekannannya yang begitu besar terhadap syari'ah. la tidak ingin 
syariah dipisahkan dari kehidupan manusia. Berbeda dengan beberapa sarjana Muslim liberal dengan merumuskan konsep maqāṣid berdasarkan Imam Syāțibītapi malah merendahkan syariah Islam.

\section{SYARI'AH ISLAM DAN MAQĀSIID ASY-SYARI'AH: KRITIK TERHADAP LIBERALIS}

Isu seputar penegakan syari'at Islam merupakan suatu tema kontroversi yang menarik perhatian berbagai kalangan. Tak kurang dari cendikiawan Muslim dan nonMuslim, aktivis Islam, LSM, politisi, dan diplomat Barat ikut terlibat memperdebatkan dan mendiskusikan isu ini. Kontroversi penegakan Syari'ah Islam dapat dikatakan baru dan belum pernah terjadi sepanjang sejarah peradaban Islam. Absennya topik seperti ini dalam khazanah literatur keilmuan Islam bukan karena kurangnya perhatian ulama terhadap isu ini. Tapi lebih cenderung karena mereka - dalam kitab-kitab fiqh, tafsir, atau 'aqidah - tidak pernah memperdebatkan apakah melaksanakan hukum Allah itu wajib atau sebaliknya. Hal ini merupakan indikasi yang jelas bahwa para ulama dan ummat Islam sepakat tentang perihal wajibnya melaksanakan syari'ah Islam. Kalaupun tidak ada kesepakatan di antara mereka, hal itu hanya berkisar seputar penafsiran dan praktiknya. Misalnya, berapakah kadar barang curian yang menjadikan seseorang pencuri itu wajib dihukum potong tangan? Apakah pemotongan itu dari pergelangan tangan atau bukan, tangan kiri atau kanan? dan lain sebagainya, sesunggunya hanya bersifat teknis (furū') bukan prinsip (ushul). Adapun hal-hal yang bersifat prinsip semuanya sepakat (Nirwan, 2004).

Isu penolakan terhadap syari'ah mengemuka seiring dengan makin menguatnya hegemoni Barat atas dunia Islam, sejatinya mempunyai latar belakang yang panjang. Sejurus jatuhnya Kekhalifahan Utsmaniyah, dunia Islam satu persatu jatuh ditangan penjajah, dan hukum perundangan Barat pun mulai diperkenalkan. Mulai saat itu debat di seputar syariah mulai bermunculan. Kontroversi ini dipicu oleh 'Ali 'Abd al-Raziq, salah seorang guru besar Al-Azhar, melalui bukunya berjudul al-Islām wa Ushul al-Hukm yang terbit 1962 (Nirwan, 2004). Buku ini secara eksplisit menolak adanya hubungan antara agama dan politik (negara) dalam Islam. Baginya Nabi Muhammad bukan seorang politisi atau pemimpin negara, tapi hanya seorang pemimpin spritual. Sebagai seorang pemimpin spritual kata Raziq, tugas Nabi hanya sebatas penyampaian risālah ruhaniyah saja, bukan mendirikan agama. Dan risalah ini, lanjutnya lagi, tidak mengatur isu-isu keduniaan seperti politik, negara, perang dan seterusnya, ajarannya hanya mencakup manusia dan Tuhan-nya (Al-Hasan, 2016). Namun belakangan, Raziq menarik ucapannya tersebut dalam sebuah wawancara pada majalah Risālah alIslām mengatakan: "ungkapan bahwa Islam adalah risālah ruhaniyah semata merupakan sebuah ungkapan yang dilemparkan syaitan ke dalam lidahku." (al-Dār alMisriyyah , 1992).

Pertentangan

penerapan syariah Islam ini menghasilkan dua kubu yang saling 
berlawanan dalam tubuh umat Islam. Liberal dan non-liberal. Kelompok liberal mendahulukan konteks sedangkanan non-liberal bervariasi ada yang yang mendahulukan teks, ada yang mendahulukan teks tapi menggunakan akal, ada yang seimbang antara teks dan konteks. Namun non-liberal masih dalam domain worldview Islam, sedangkan liberal telah dihegemoni oleh wordlview Barat postmodern (Zarkasyi, 2012).

Semakin gencar gerakan menuntut pelaksanaan Syariat Islam, semakin kuat pula suarasuara penantangan terhadapnya. Yang paling menyedihkan penentangan ini dilakukan oleh kalangan Muslim sendiri yang bukan dari golongan awam tapi mereka yang terdidik dan terpelajar. Misalnya, Abdullah Ahmad an-Na'im, Syari'at Islam, jelasnya, bukanlah totalitas ajaran Islam, tapi hanya interpretasi ulama atas sumber hukum Islam. Oleh karena ia hasil konstruksi ulama, maka kemungkinan untuk merubahnya tentunya, katanya lagi, masih terbuka luas (An-Naim, 2007). Pandangan An-Na'im ini tentu sangat berbahaya, dan menimbulkan implikasi yang sangat fatal. Karena, akan memberi ruang kepada umat Islam untuk menolak syariat Islam. Kemudian yang lebih berbahaya lagi An-Naim berusaha mengubah syariah agar sesuai dengan konstitusionalisme, hukum kriminal, hubungan international, dan hak asasi manusia (HAM). Bahkan lebih parah dari itu, an-Na'im menuduh, "Shari'ah telah memperkosa hal yang paling mendasar dari hak asasi manusia standar internasional (Nirwan, 2004).
Senada dengan an-Na'im, Nasr Hamid Abu Zayd mengatakan bahwa al-Qur'an muntaj tsaqafi (produk budaya). Apa yang tersirat dari pandangan-pandangan ini adalah bahwa hukum-hukum yang terkandung dalam al-Qur'an penuh dengan nuansa tatanan sosialbudaya, ekonomi, dan politik masyarakat Arab abad ketujuh (Nirwan, 2004).

Fazhlur Rahman, bahkan menawarkan tafsir model baru untuk memahami hukum-hukum yang ada didalam al-Qur'an. Rahman mencoba menawarkan penafsiran kontekstual dan hermeneutika terhadap Al-Qur'an. Karena tafsir klasik dianggap gagal dalam memaparkan pesan-pesan AI-Qur'an secara komprehensif yang telah menjadikan bencana besar dalam theologi (Rahman, 1985). Begitu juga dengan Abdullah Saeed yang menganggap ada gap antara kebutuhan muslim sekarang yang berkembang sedemikan pesat dan kompleks dengan pemahaman ayatayat al-Qur'an yang masih diinterpretasikan secara literal dan diaplikasikan dalam kehidupan sehari-sehari sebagaimana kehidupan sosio-religius pada awalawal Islam. Karena menurutnya, realitas konteks masyarakat sekarang berbeda dengang sosiohistoris masyarakat 14 abad yang lalu (Saeed, 2006).

Nampaknya, kerangka berfikir kaum liberalis ini dibangun atas dua argumen. Pertama, bahwa al-Qur'an adalah respon spontan terhadap kondisi masyarakat ketika itu, dan bahwa hukum-hukum figh seperti yang disebutkan di atas adalah produk ijtihad ulama abad pertengahan. Kedua, bahwa tujuan ditetapkannya hukum syari'ah itu 
bukan sekedar untuk memenuhi formal legalistiknya saja tetapi lebih jauh dari pada itu, yaitu untuk menciptakan mashlāhah kepada umat manusia.

Sesungguhnya ide-ide inilah yang telah diboyong dan diusung oleh kelompok liberal di Indonesia. Seperti Ulil Abshar Abdallah, Lufi Asy-Syaukani, Mosyqit al-Ghazali, Sumanto al-Qurthubi, Siti Musdah Mulia, Nong Darol Mahmadah, dll. Gerakan ini nampaknya sudah sangat berpangaruh sekali dengan ide-ide di atas. Seperti dapat dibaca dengan jelas dari artikel Ulil Abshar Abdallah yang berjudul "Menyegarkan Kembali Pemahaman Islam" (Kompas, 18/11/2002). Ulil Mengatakan:

Jalan satu-satunya menuju kemajuan Islam adalah dengan mempersoalkan cara kita menafsirkan agama ini. Untuk menuju ke arah itu, kita memerlukan beberapa hal. Pertama, penafsiran Islam yang non-literal, substansial, kontekstual, dan sesuai denyut nadi peradaban manusia yang sedang dan terus berubah. Kedua, penafsiran Islam yang dapat memisahkan mana unsur-unsur di dalamnya yang merupakan kreasi budaya setempat, dan mana yang merupakan nilai fundamental. Kita harus bisa membedakan mana ajaran dalam Islam yang merupakan pengaruh kultur Arab dan mana yang tidak.

...Yang harus diikuti adalah nilai-nilai universal yang melandasi praktik-praktik itu. Jilbab intinya adalah mengenakan pakaian yang memenuhi standar kepantasan umum (public decency). Kepantasan umum tentu sifatnya fleksibel dan berkembang sesuai perkembangan kebudayaan manusia. Begitu seterusnya.

Wajar banyak pihak menilai artikel itu tidak membawa ide yang baru, apalagi menyegarkan. la hanyalah artikulasi baru atau bahkan "carbon copy" dari kesimpulankesimpulan para penulis liberal seperti an-Naim, Nasr Hamid Abu Zaid, dll.

Sebagai contoh yang lain dari pemikiran nyeleneh kelompok ini (Jaringan Islam Liberal/JIL), Sumanto Al-Qurthubi seorang alumnus IAIN Semarang dan mengambil doktor di Boston University, menulis dalambukunya Melawan Ekstrimis Agama, Membangkitkan Islam Progresif, dia mengatakan:

Lalu bagaimana hukum hubungan seks yang dilakukan atas dasar suka sama suka, "demokratis", tidak ada pihak yang disubordinasi" dan "diintimidasi"? Atau bagaimana hukum orang yang melakukan hubungan seks dengan pelacur (maaf kalau kataini kurang sopan), dengan escort lady, call girl dan sejenisnya? Atau hukum seorang perempuan, tante-tante, janda-janda atau wanita kesepian yang menyewa seorang gigolo untuk melampiaskan nafsu seks? Jika seorang dosen atau penulis boleh "menjual" otaknya untuk mendapatkan honor, atau seorang da'i atau pengkhotbah yang "menjual" mulut untuk mencari nafkah, atau penyanyi dangdut yang "menjual" pantat dan pinggul untuk mendapatkan uang, atau seorang penjahit atau pengrajin yang "menjual" tangan untuk menghidupi keluarga, apakah tidak boleh seorang laki-laki atau perempuan yang "menjual" alat kelaminnya untuk menghidupi anak-istri/suami mereka?." (Husaini, 2010) 
Kaum liberal yang memperjuangkan maqāșid syarīah justru menetang penerapan syari'ah, sedangkan penerapan syariah adalah cara untuk mengembalikan dan mereliasasikan kembali prinsip maqāșid. Liberalis hanya ingin mengambil maqāșid-nya dan meninggakan syariahnya. Tentu hal ini sangat ambigu. Yang menjadi pertanyaan, apakah bisa maqāșid bisa didapatkan sementara perintah pelaksaan syariah tidak dilaksanakan? Mungkin saja maslāhah bisa didapatkan dengan tanpa penerapan syariah, tapi apakah bisa sesempurna jika syariah diterapkan?

Sebagai contoh ambiguitas mereka adalah ejekan mereka (liberalis) terhadap hukum hudud. Seperti diterangkan di atas kaum liberalis menolak hukum hudud dengan alasan hukum ini sudah outdate, tidak dapat merealisasikan apa yang menjadi tujuan utama dari hukum tersebut, yaitu memberikan ketentraman dan keamanan kepada harta dan jiwa, serta masyarakat.

Benarkah hukum hudud tidak dapat mewujudkan kemaslahatan bagi manusia hari ini? Mari kita teliti lebih dalam. Setiap hukuman mempunyai tujuan ganda. Pertama, untuk menciptakan keadilan bagi yang teraniaya, dan disini diperlukan prinsip retributive, dan kedua sebagai pelajaran bagi masyarakat banyak, atau selalu disebut dengan dettrerance. Apa saja hukuman yang tidak setimpal dengan kejahatan yang dilakukan hanya akan menciptakan kekacauan yang lebih hebat. Sebagai contoh, apabila keluarga yang terbunuh tidak merasa puas dengan hukuman yang dijatuhkan terhadap pembunuh maka akan timbul kekecewaan, dan kekecewaan akan mendorong reaksi yang tidak rasional. Orang tersebut mungkin akan melakukan pembalasan pembunuhan, mungkin terhadap si pelaku atau kepada keluarga terdekat si pembunuh. Apa bila pihak yang terbunuh juga tidak merasakan keadilan, maka dia juga akan melakukan tindakan yang sama sehingga akan terjadi escycling pembunuhan, dan pada akhirnya akan menciptakan ketakutan di tengah-tengah masyarakat. Apakah ada hukuman yang lebih kejam bagi si orang yang menciptkan huru-hara selain hukuman bunuh itu sendiri. Jadi dengan hukum hudud, prinsip keadilan yang merupakan bagian penting dari obyektif syariah telah terlaksana. Lantas kenapa golongan liberalis menolak hukuman hudud?

\section{KESIMPULAN}

Dilihat dari dua perspektif hukum tadi, jelas sekali bahwa fungsi hukum memiliki fungsi ganda. Namun demikian, disini kita perlu menekankan bahwa hukum hudud bukanlah satu-satunya syariah Islam. Syariah Islam bukan hanya hudud, rajam, waris, dan sejenisnya. Syariah Islam jauh lebih komprehensif dan sempurna. Syariah Islam termasuk kewajiban untuk menyantuni anak yatim, memberdayakan ekonomi ummah, memilih pemimpin yang jujur dan bertanggung jawab, bersikap jujur dan seterusnya hingga mengantur negara. Tuduhan bahwa kelompok pro-syariah (revivalis) mereduksi ajaran Islam hanya kepada hudud, qishas, jilbab, dan poligami saja, adalah sama sekali tidak berdasar. Sesungguhnya penuduh itulah yang mereduksi hukum Islam kepada masalah-masalah tadi. Lihatlah, 
kebanyakan para pengecam syari'ah itu biasanya mengkritik hukumhukum seputar hudud dan sebagainya. Seperti Abdullah Ahmed an-Na'im mendedikasikan dirinya mencerca dan mengejek hukum Allah seperti hudud dan sejenisnya. Bukankah contoh-contoh yang selalu diangkat Fazlur Rahman, Mohammed Arkoun, 'Abid Al-Jabiri, Syahrur dan yang seperti mereka berputar sekitar hudud, poligami, hukum warisan, dan sejenisnya? Dengan berbagai pendekatan mereka sampai pada kesimpulan yang sama, yaitu menggugat hukum Islam.

Menurut Abdul Majid al-Najjar akar permasalahan disini terletak pada kesalahan liberalis yang mencoba memisahkan antara maqsad (obyektif) dan hukum yang menjadi wasilah kepada tujuan/obyektif. Padahal sesunggunya dua aspek itu adalah satu. Antara hukum dan tujuan hukum adalah satu ikatan yang tak terpisahkan. Apa yang Allah perintahkan pasti tentulah akan mendatangkan kebaikan, dan apa yang dilarang jelas akan menimbulkan kerusakan (Husaini, 2010).

Aksioma yang mengatakan "dimana ada maslahah, disitu pasti ada syariah", kata Qardhawi tida selalu benar. Menurutnya lagi, aksioma itu seharusnya berbunyi "haytsuma wujida al-Syar'i fa tsamma al-maslahah" (dimana ada hukum syara' pasti ada mashlāhah). Ini terkadang apa yang dianggap sebagai mashlāhah sebenarnya bukan mashlāhah, bisa jadi ia sudah menjadi mashlāhahmulgha (dibatalkan), seperti khamar, terdapat mashlahah tetapi dibatalkan oleh Allah karena mengandung keburukan yang lebih besar. Sebagai kesimpulan, tidak mungkin Allah menysari'ahkan sesuatu tanpa ada tujuan (maqashid al-syari'ah) yang berupa maslahat, meskipun terkadang akal kita tidak dapat menangkap dan memahami mashlāhah tersebut. Wallahu A'lam.

\section{DAFTAR PUSTAKA}

Al-Dār al-Misriyyah , 1992. Misr bayn al-Dawlah al-Diniyyah wa alMadaniyyah. Kairo, al-Dār alMisriyyah

Al-Hasan, Abu. 2016. Hadist Arba'in Nawawiyyah, Maktabah Alhanif. Yogyakarta.

Al-Raysuni, Ahmad, 2005, Imam alShatibi's: Theory of The Higher Objectives and Intens of Islamic Law, Herdon: IIIT.

Al-Syathibi, Ibrahim ibn Musa Abu Ishaq, 1997,al-Muwafaqat fi Ushul al-Ahkam, KSA: Dar lbn Affan.

An-Naim, Abdullah Ahmed, 2007, Islam dan Negara Sekular, Menegosiasikan Masadepan Syari'ah, Mizan: Bandung.

Anwar, Syamsul, 2007, Hukum Perjanjian Syariah, Jakarta: Rajawali Press.

Arma, Nirwan Syarfrin, 2004, "Syari'at Islam: Antara Ketetapan Nas dan Maqasid Syariat,"Jurnallslamia, Thn. 1 No. 1.

Asmuni, 2012, "Teoritisi al-Maqashid: Upaya Pelacakan Historis", dalam Pribumisasi Hukum Islam, Yogyakarta: PSI-MSI.

Auda, Jasser, 2007, Maqasid alShariah as Philosophy of Islamic Law, A systems Approach, London: IIUT.

Husaini, Adian, 2010, Liberalisasi Pendidikan Tinggi, Seminar 
Al-Fikra: Jurnal IImiah Keislaman, Vol. 17, No. 2, Juli-Desember, 2018 (205217)

tentang Sekularisasi dan Liberalisasi Islam di Perguruan

Tinggi, oleh Keluarga Mahasiswa Islam ITB, ITB, 23 Mei 2010

Qayyim, Ibnu, tanpa tahun, 'illamalMuwaqi'in 'an Rabb al-'Alamin al-Muqarramin, Jeddah: Dar Ibnu Al-Jauzi.

Rahman, Fazlur, 1985, Islam dan Modernitas,

Tentang

Transformasi Intelektual, Bandung: Pustaka.

Saeed, Abdullah, 2006, Saeed, Interpreting the Qur'an:

Toward a Contemporary Approach, Madison Ave: Routladge.

Tim Penulis MSI-UII, 2012,Pribumisasi Hukum Islam, Yogyakarta: MSI-UII,

Zarkasy, Hamid Fahmi, 2012, Misykat: Refleksi Tentang Westernisasi, Liberalisasi, dan Islam, Jakarta: INSIST-MIUMI. 